\section{Wesley M. Hill - A Profile}

\section{IUGS Councillor (2010-2014)}

Born in 1969 in New Orleans, Louisiana USA, Wesley Hill spent most of her early life in the Southern region of America including completing her BSc in Forest Management from the University of Arkansas in 1993. While still completing her degree, she was

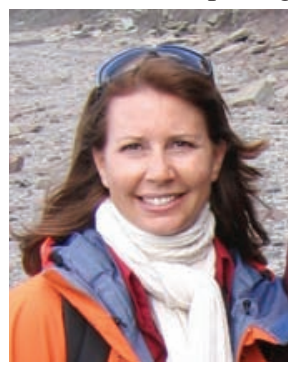
hired as a co-op student for the United States Forest Service in Driggs, Idaho at the Teton Basin Ranger Station and began her work in backcountry Wilderness Management in the heart of the Teton mountain range in the states of Wyoming and Idaho, USA. Wesley managed the 143,000 acre Jedediah Smith Wilderness area bordering Grand Teton National Park which included backcountry monitoring of hikers and backpackers, avalanche search and rescue, fire fighting, trail building, supervising additional summer ranger staff, and ensuring all visitors were informed and abiding by the 'camping in bear country' camping and hiking regulations since many grizzly and black bears lived in the immediate area.

From her start in Wilderness Management and passion for environmental education, Wesley transferred with the U.S. Forest Service to Flagstaff, Arizona to work in the Kaibab National Forest which is the watershed forest that protects and surrounds the Grand Canyon on both the North and South rims. On the Kaibab, Wesley directed the education and interpretation program including supervising the education and visitor services staff, and developing all the educational 'ranger programs' where visitors can join a ranger led hike and tour on subjects like geology, archaeology, wildlife and American Indian culture. The most rewarding project was designing and building the large scale museum exhibits at the tourism center which focuses on the geology, area history, archaeology and American Indian tribal culture and took over five (5) years to complete.

From Arizona, Wesley took another job transfer to work in Denver, Colorado in the U.S. Forest Service Western Regional Office to develop and implement a national and global radio program on environmental education. The educational radio program focused on scientific interviews from scientists working in geology, ecology, wildlife management, energy, mapping, water, soils, etc. and was heard by over a million people per program per day. All interviews and subject matter focused on scientists working with National Parks, National Forests, and other natural protected areas both in the United States and abroad.

After the global success of the radio program, Wesley took another job with the U.S. Forest Service in tourism management which focused on outdoor recreation and ecotourism. From her position in tourism, she moved to Paris, France to assist the United Nations Environment Programme (UNEP) and United Nations Educational Scientific and Cultural Organization (UNESCO) during the 2002 International Year of Ecotourism and organizing the World Ecotourism Summit in Quebec, Canada. Wesley's primary activities during the International Year, were to build a UNESCO World Heritage focus into the UNEP sponsored conferences in East Africa, Mesoamerica, and South East Asia.

After the International Year of Ecotourism, Wesley moved from Paris back to the United States and took a position as Development Officer with The Nature Conservancy, a global conservation NGO. From The Nature Conservancy, Wesley moved to Boulder, Colorado to take a position with the Geological Society of America (GSA) to manage the GeoCorps America Program which places early career geoscientists and seasoned guest scientists on America's most geologically significant protected areas, such as the Grand Canyon, Yellowstone, and Denali National Parks. From building and managing the GeoCorps program, GSA's Executive Director asked Wesley to move departments and work for him in the Executive Office to manage GSA's International Program as well as manage various leadership programs within GSA. In her current position as GSA International Liaison, Wesley has been very involved in UNESCO World Heritage and the Global Geoparks Network and is the main U.S. contact for the blooming U.S. Geoparks program. Today, Wesley is very involved in GSA international meetings, managing GSA's international member programs, strategic leadership initiatives, an annual GSA International Lecture Tour, UNESCO initiatives, and developing and launching a U.S. Geoparks program. Wesley's Councilor term on the IUGS Executive Committee began in August 2010 when she quickly jumped into leading various projects concerning the IUGS 50 ${ }^{\text {th }}$ Anniversary.

Wesley was the Secretary/Treasurer for the U.S. National Committee for IYPE from 2007-2009 as well as the Secretary/Treasurer for the IUGS Commission on Geoscience Education, Training and Technology Transfer from $2004-2008$. Wesley is currently a member of the IUCN World Commission on Protected Areas, liaison member on the U.S. National Committee for Geological Sciences, and the U.S. ad hoc member of the Canada National Committee for Geoparks. 